\title{
Pengembangan Perekat Alam untuk Penyambung Artefak Tahap II
}

\author{
Leliek Agung Haldoko, Iskandar M. Siregar, Yudi Suhartono, \\ Linus Setyo Adidhuto, Ajar Priyanto \\ Balai Konservasi Borobudur \\ Email : leliek_agung@yahoo.co.id
}

\begin{abstract}
Abastrak: Salah satu Cagar Budaya berbahan kayu adalah artefak. Faktor fisik maupun mekanik dapat menyebabkan artefak menjadi retak atau patah. Untuk menyambungfragmen-fragmen yang patah tentunya dibutuhkan perekat. Perekat yang diuji dalam kajian ini meliputi perekat dari bahan tanin dan gondorukem.

Perekat dari tanin dan gondorukem dikombinasikan dengan berbagai macam pelarut. Untuk bahan tanin digunakan pelarut aceton, etanol dan formaldehyde, sedangkan untuk bahan gondorukem digunakan pelarut tiner, minyak cat dan toluol.Pengujian daya tahan perekat dilakukan dengan siklus yang terdiri dari 3 (tiga) perlakuan, yaitu menempatkan sampel kayu yang direkat pada suhu $50^{\circ} \mathrm{C}$, pada kondisi kelembaban $95 \%$ dan pada suhu kamar.Untuk pengujian kekuatan perekat dilakukan dengan pengujian kualitatif kekuatan rekat dengan beban statis dan pengujian kuat geser.

Pengujian daya tahan perekat diperoleh hasil bahwa perekat dengan bahan tanin-aceton dan tanin-etanol tidak tahan terhadap kondisi kelembaban udara yang tinggi dan memiliki daya rekat yang rendah. Hal ini diketahui setelah dilakukan pengujian kualitatif dengan menggunakan beban statis.

Berdasarkan pengujian kuat geser diperoleh hasil bahwa perekat gondorukem-toluol memiliki daya rekat paling besar, yaitu $14,83 \mathrm{~kg} / \mathrm{cm}^{2}$; berturut-turut selanjutnya tanin-formaldebyde $9,95 \mathrm{~kg} / \mathrm{cm}^{2}$; gondorukem-tiner 9,52 $\mathrm{kg} / \mathrm{cm}^{2}$; dan gondorukem-minyak cat $4,81 \mathrm{~kg} / \mathrm{cm}^{2}$.
\end{abstract}

Kata kunci : perekat alam, perekat kayu, artefak kayu, tanin, gondorukem

Abstract : Artefact is one of wooden cultural heritage, which can crack or brake because of mechanical or physical factors. In order to repair the cracked or broken fragments, adhesive materials are needed. Tannin and gondorukem are known for their adhesive character, but they need to be tested scientifically.

Adhesive from tannin and gondorukem is combined with various solvents. For tannin material, acetone solvent, ethanol and formaldehyde are used, while thinner solvent, paint oil and toluol are used for gondorukem materials. The test of adhesive endurance is carried out with a cycle consisting of 3 (three) treatments, placing a sample of wood that is sealed at $50^{\circ} \mathrm{C}$ temperature, at $95 \%$ humidity conditions and at room temperature. The adhesive strength testing is carried out by testing the adhesive strength with static load and shear strength testing.

Based from the adhesive endurance test, it was found that adhesive with tannin-acetone and tannin-ethanol were not resistant to high air humidity and the solvent have very low adherence after being tested using a static load Based on the shear strength test, the result shows that the gondorukem-toluol adhesive has the greatest adhesion $14,83 \mathrm{~kg} / \mathrm{cm}^{2}$; and for the next are subsequently tannin-formaldehyde $9,95 \mathrm{~kg} / \mathrm{cm}^{2}$; gondorukem-thinner 9,52 $\mathrm{kg} /$ $\mathrm{cm}^{2}$; and gondorukem-paint oil $4,81 \mathrm{~kg} / \mathrm{cm}^{2}$.

Keywords : natural adhesives, wood adhesives, wooden artifacts, tannin, gondorukem

\section{Latar Belakang}

\subsection{Latar Belakang}

Cagar Budaya merupakan salah satu kekayaan budaya bangsa yang penting artinya bagi pemahaman dan pengembangan sejarah, ilmu pengetahuan dan kebudayaan, sehingga penting untuk dijaga kelestariannya. Cagar budaya di Indonesia tersusun atas berbagai jenis material, antara lain kayu. Cagar budaya berbahan kayu salah satunya adalah berupa artefak.

Kayu merupakan benda organik sehingga dapat mengalami kerusakan dan pelapukan yang disebabkan oleh faktor mekanik, biologi, fisik dan lingkungan. Faktor fisik dan mekanik dapat menyebabkan kerusakan berupa retak maupun patah. Untuk menyambung fragmen-fragmen yang patah tentunya dibutuhkan perekat.

Adhesive atau lem atau juga sering disebut perekat merupakan suatu bahan yang digunakan untuk menyatukan dua benda yang sejenis, maupun yang tidak sejenis bersama dengan aksi permukaan, sehingga kedua benda tersebut bisa bertahan 
terhadap aksi pemisahan (Suryana, 2013).

Perekat sintetis seperti urea formaldehida, fenol formaldehida dan melamin formaldehida memiliki kelemahan, antara lain adalah ketersediaan sumber bahan baku perekat yang semakin berkurang dan timbulnya emisi formaldehida dari produk material hasil perekatan terhadap lingkungan. Emisi formaldehida dapat menyebabkan gejala pusing, sakit kepala dan insomnia (Umemura, 2006)

Perekat alam diharapkan dapat memberikan alternatif yang dapat digunakan untuk penyambungan artefak kayu. Selain mudah didapat dan harganya relatif murah, perekat alam juga lebih ramah lingkungan dan ketersediaannya cukup banyak serta dapat diperbaharui. Sebelum diaplikasikan pada sebuah Cagar Budaya, tentunya perekat harus diteliti terlebih dahulu untuk mengetahui daya rekat, efektivitas, serta kelebihan dan kekurangannya. Oleh karena itu, perlu dilakukan kajian pengembangan perekat alam untuk penyambungan artefak kayu.

Pada tahun 2015, Balai Konservasi Borobudur mulai melakukan kajian terhadap perekat alam untuk penyambungan artefak kayu. Bahan-bahan yang dipakai berasal dari hewan maupun tumbuhan, yaitu anchor, gelatin, tanin, dextrin dan gondorukem. Hasil dari kajian tersebut, bahan-bahan yang diuji memiliki karakteristik yang berbeda dari segi kenampakan (visual), derajat keasaman $(\mathrm{pH})$, berat jenis, waktu pengeringan dan daya rekat. Pada tahun 2016, kajian hanya menitikberatkan pada 2 (dua) jenis bahan perekat, yaitu tanin dan gondorukem. Pemilihan tanin dan gondorukem didasrkan pada kajian sebelumnya, yang menunjukkan bahwa kedua bahan ini tidak ditumbuhi jamur selama proses pengeringannya, baik ketika diaplikasikan terhadap kayu maupun pada sisa bahan perekat yang tidak terpakai. Selain itu, kedua bahan ini mudah untuk diperoleh ataupun dibuat sendiri. Pengujian kedua bahan ini dikembangkan pada pencampuran dengan beberapa macam pelarut untuk mendapatkan daya tahan dan kekuatan rekat yang optimal.

\subsection{Metode}

Bahan-bahan yang digunakan dalam kajian ini antara lain: serbuk tanin, gondorukem, etanol, aceton, formaldehyde, tiner, minyak cat, toluol, aquadest dan sampel kayu jati. Sedangkan alat-alat yang digunakan adalah: gelas beker, cawan petri, kompor listrik, spatula, timbangan, oven, inkubator dan universal testing machine.

Tahap pertama yang dilakukan adalah studi pustaka untuk mencari data sekunder yang dapat menunjang kajian ini. Selanjutnya dilakukan percobaan laboratorium yang meliputi:

a. Pembuatan perekat dari bahan alam

Perekat berasal dari bahan tanin dan gondorukem. Pelarut yang dipakai untuk tanin, yaitu etanol, aceton dan formaldebyde. Sedangkan pelarut yang dipakai untuk gondorukem adalah tiner, minyak cat dan toluol. Perbandingan bahan dan pelarut adalah 1:1, masing-masing 20 gram untuk bahan dan $20 \mathrm{ml}$ untuk pelarut.

b. Persiapan kayu yang direkat

Kayu jati digunakan sebagai media perekatan, karena banyak artefak yang berbahan kayu jati. Ada dua jenis sampel kayu yang digunakan.

Sampel 1, kayu dipotong berbentuk balok dengan ukuran 3x 1,5 x 5,5cm. Selanjutnya balok kayu dibelah menjadi dua bagian dengan ukuran 1,5 x 1,5 x 5,5 cm, dan permukaannya diamplas sampai halus. Sampel 2, kayu dipotong berbentuk balok dengan ukuran 15 x 7 x 4cm. Selanjutnya kayu dipotong di bagian tengah dengan kemiringan $45^{\circ}$ sehingga terbagi menjadi dua bagian sama besar.

Balok kayu dikeringkan secara alami sampai kadar air $\pm 15 \%$. Selanjutnya dilakukan pengukuran panjang dan lebar permukaan yang akan direkat secara teliti menggunakan jangka sorong.Bagian permukaan dioles dengan perekat pada kedua sisinya secara merata, kemudian direkatkan sampai tersambung sempurna dan dibiarkan mengering secara alami.

c. Pengujian daya tahan perekat (aging test)

Pengujian daya tahan perekat dilakukan dengan siklus yang terdiri dari 3 (tiga) perlakuan, yaitu menempatkan sampel kayu yang direkat pada suhu $50^{\circ} \mathrm{C}$, pada kondisi kelembaban 95\% dan pada suhu kamar. Pengujian ini didasari pada kondisi suhu dan kelembaban udara yang 
ekstrim yang terjadi pada lokasi penyimpanan artefak kayu. Penempatan pada suhu $50^{\circ} \mathrm{C}$ dilakukan dalam oven, sedangkan untuk kondisi kelembaban 95\% ditempatkan pada inkubator. Setiap perlakuan dalam 1 (satu) siklus dilakukan selama 24 jam dengan jumlah keseluruhan sebanyak 10 siklus. Pengujian ini bertujuan untuk melihat ketahanan sampel kayu yang telah direkatkansetelah melewati siklus tersebut.

d. Pengujian kekuatan rekat

1) Pengujian kualitatif kekuatan rekat dengan beban statis

Metode inimerupakan pengujian secara kualitatif untuk membandingkan kekuatan perekat pada sampel kayu yang diberikan pemberat dalam posisi diam. Pengujian berturut-turut dilakukan tanpa memberikan pemberat,kemudian dengan pemberat masing-masing 0,5 kg; $1 \mathrm{~kg} ; 1,5 \mathrm{~kg}$ dan $2 \mathrm{~kg}$. Lama waktu pengujian adalah sebagai berikut :

\begin{tabular}{|l|l|}
\hline \multicolumn{1}{|c|}{ Pemberat } & \multicolumn{1}{c|}{ Waktu } \\
\hline Tanpa Pemberat & 168 jam (7hari) \\
\hline $0,5 \mathrm{~kg}$ & 48 jam (2 hari) \\
\hline $1 \mathrm{~kg}$ & 48 jam (2 hari) \\
\hline $1,5 \mathrm{~kg}$ & 48 jam (2 hari) \\
\hline $2 \mathrm{~kg}$ & 168 jam (7 hari) \\
\hline
\end{tabular}

Sampel yang lolos pengujian secara kualitatif (perekat tidak lepas sampai pengujian dengan pemberat $2 \mathrm{~kg}$ selama 7 hari) akan dilanjutkan dengan pengujian kuat geser

2) Pengujian kuat geser

Pengujian kuat geser perekat dilakukan dengan menguji sampel kayu yang direkat dengan alatuniversal testing machine. Pengujian ini dilakukan untuk mengetahui kekuatan perekatan masing-masing bahan yang dibuat dengan macam-macam pelarut.

Data yang didapatkan selanjutnya dilakukan analisis dan komparasi antar bahan untuk mengetahui jenis bahan dan pelarut yang menghasilkan daya tahan dan daya rekat yang paling optimal.
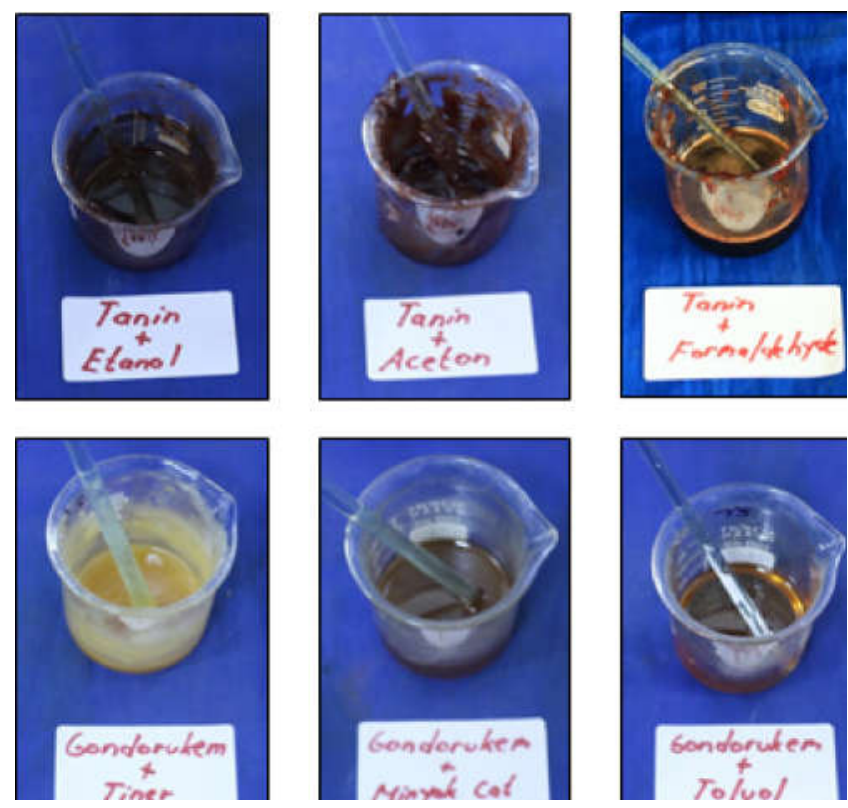

Gambar 1. Perekat dari tanindangondorukem

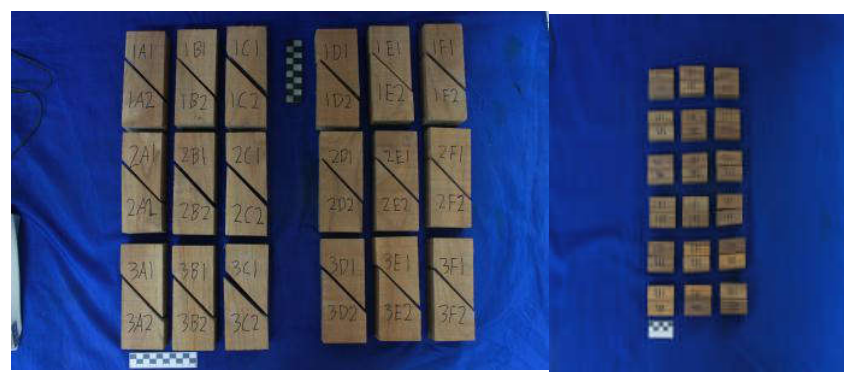

Gambar 2. Sampel kayu sebelum dilakukan perekatan

Tabel 1. Pengkodean sampel kayu yang direkat

\begin{tabular}{|c|c|c|}
\hline \multicolumn{3}{|c|}{ Sampel kayu yang direkat } \\
\hline Kode & Bahan & Pelarut \\
\hline $1 \mathrm{~A} 1-1 \mathrm{~A} 2$ & & \multirow{3}{*}{ Etanol } \\
\hline 1B1-1B2 & & \\
\hline $1 \mathrm{C} 1-1 \mathrm{C} 2$ & & \\
\hline $2 A 1-2 A 2$ & \multirow{3}{*}{ Tanin } & \multirow{3}{*}{ Aceton } \\
\hline 2B1-2B2 & & \\
\hline 2C1-2B2 & & \\
\hline $3 A 1-3 A 2$ & & \multirow{3}{*}{ Formaldehyde } \\
\hline 3B1-3B2 & & \\
\hline $3 C 1-3 c 2$ & & \\
\hline 1D1-1D2 & & \multirow{3}{*}{ Tiner } \\
\hline 1E1-1E2 & & \\
\hline 1F1-1F2 & & \\
\hline 2D1-2D2 & \multirow{3}{*}{ Gondorukem } & \multirow{3}{*}{ Minyak cat } \\
\hline 2E1-2E2 & & \\
\hline $2 \mathrm{~F} 1-2 \mathrm{~F} 2$ & & \\
\hline 3D1-3D2 & & \multirow{3}{*}{ Toluol } \\
\hline 3E1-3E2 & & \\
\hline $3 F 1-3 F 2$ & & \\
\hline
\end{tabular}




\section{Pembahasan}

\subsection{Percobaan Perekatan}

Percobaan pembuatan perekat dari tanin, pada waktu yang bersamaan langsung dapat diaplikasikan pada kayu.Perekat dari gondorukem relatif berbentuk cair dan membutuhkan waktu untuk dapat diaplikasikan pada sampel.

Perekat diaplikasikan pada sampel kayu untuk pengujian daya tahan perekat, pengujian kualitatif kekuatan rekat dengan beban statis dan kuat geser.

\subsection{Pengujian Daya Tahan Perekat (Aging Test)}

Pengujian daya tahan perekat ini dilakukan sebanyak 10 siklus. Hasil pengujian dapat dilihat pada Tabel 2 berikut ini:

\section{Tabel 2. Pengujian Daya Tahan Perekat}

\begin{tabular}{|c|c|c|}
\hline Siklus & Perlakuan & Kondisi Perekatan \\
\hline \multirow{3}{*}{$\begin{array}{l}\text { Siklus } \\
1\end{array}$} & Temperatur $50^{\circ} \mathrm{C}$ & 6 perekat dalam kondisi baik \\
\hline & Kondisi ruangan & 6 perekat dalam kondisi baik \\
\hline & Kelembaban $95 \%$ & $\begin{array}{c}2 \text { perekat lepas } \\
\text { (tanin+etanol, tanin+aceton) }\end{array}$ \\
\hline \multirow{3}{*}{$\begin{array}{l}\text { Siklus } \\
2\end{array}$} & & 4 perekat dalam kondisi baik \\
\hline & Kondisi $r$ & 4 perekat dalam kondisi baik \\
\hline & Kelembaban $95 \%$ & 4 perekat dalam kondisi baik \\
\hline \multirow{3}{*}{$\begin{array}{l}\text { Siklus } \\
\quad 3\end{array}$} & Temperatur $50^{\circ} \mathrm{C}$ & 4 perekat dalam kondisi baik \\
\hline & Kondisi ruangan & 4 perekat dalam kondisi baik \\
\hline & Kelembaban $95 \%$ & 4 perekat dalam kondisi baik \\
\hline \multirow{3}{*}{$\begin{array}{l}\text { Siklus } \\
4\end{array}$} & Temperatur $50^{\circ} \mathrm{C}$ & 4 perekat dalam kondisi baik \\
\hline & Kondisi I & 4 perekat dala \\
\hline & Keler & 4 perekat dalam $k$ \\
\hline \multirow{3}{*}{$\begin{array}{l}\text { Siklus } \\
\quad 5\end{array}$} & Temperatur $50^{\circ} \mathrm{C}$ & 4 perekat dalam \\
\hline & Kondisi ruangan & 4 perekat dalam kondisi baik \\
\hline & Kelemb & 4 perekat dalam kondisi baik \\
\hline \multirow{3}{*}{$\begin{array}{l}\text { Siklus } \\
\quad 6\end{array}$} & Temperatur $50^{\circ} \mathrm{C}$ & 4 perekat dalam kondisi baik \\
\hline & Kondisi ruangan & 4 perekat dalam kondisi baik \\
\hline & & 4 perekat dalam kondisi baik \\
\hline \multirow{3}{*}{$\begin{array}{l}\text { Siklus } \\
\quad 7\end{array}$} & Temperatur $50^{\circ} \mathrm{C}$ & 4 perekat dalam kondisi baik \\
\hline & Kondisi ruangan & 4 perekat dalam kondisi baik \\
\hline & Kelembaban $95 \%$ & 4 perekat dalam kondisi baik \\
\hline \multirow{3}{*}{$\begin{array}{l}\text { Siklus } \\
\quad 8\end{array}$} & Temperatur $50^{\circ} \mathrm{C}$ & 4 perekat dalam kondisi baik \\
\hline & Kondisi ruangan & 4 perekat dalam kondisi baik \\
\hline & Kelembaban $95 \%$ & 4 perekat dalam kondisi baik \\
\hline \multirow{3}{*}{$\begin{array}{l}\text { Siklus } \\
9\end{array}$} & Temperatur $50^{\circ} \mathrm{C}$ & 4 perekat dalam kondisi baik \\
\hline & Kondisi ruangan & 4 perekat dalam kondisi baik \\
\hline & Kelembaban $95 \%$ & 4 perekat dalam kondisi baik \\
\hline \multirow{3}{*}{$\begin{array}{l}\text { Siklus } \\
10\end{array}$} & Temperatur $50^{\circ} \mathrm{C}$ & 4 perekat dalam kondisi baik \\
\hline & Kondisi ruangan & 4 perekat dalam kondisi baik \\
\hline & Kelembaban 95\% & 4 perekat dalam kondisi baik \\
\hline
\end{tabular}

Keterangan : kondisi baik berarti perekat tidak lepas dan masih merekat kuat

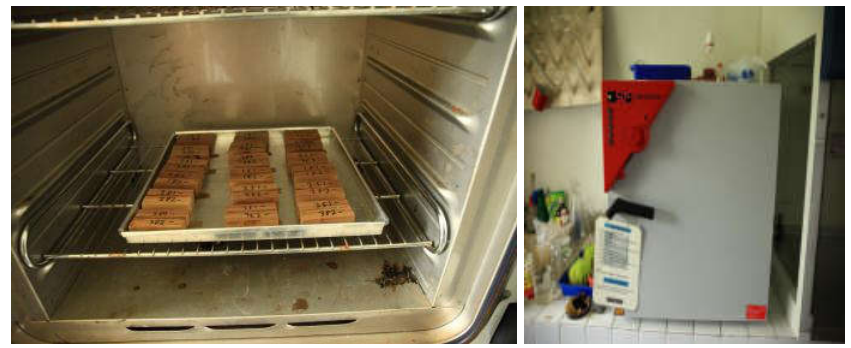

Gambar 3. Sampel kayu yang direkat ditempatkan dalam oven dengan temperatur $50^{\circ} \mathrm{C}$

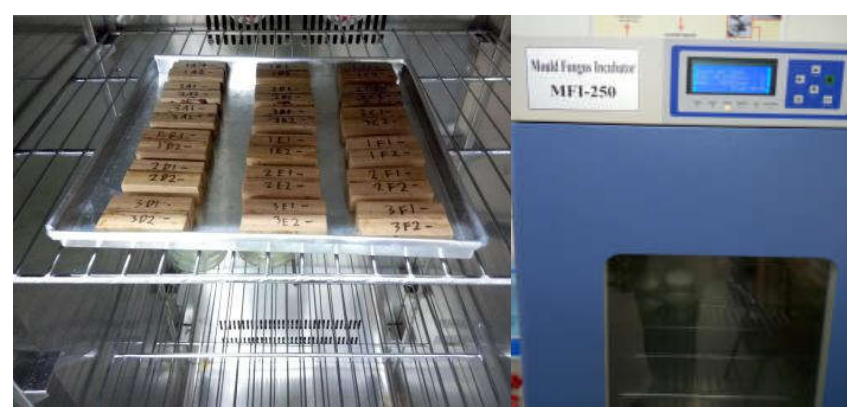

Gambar 4. Sampel kayu yang direkat ditempatkan dalam inkubator dengan kelembaban $95 \%$

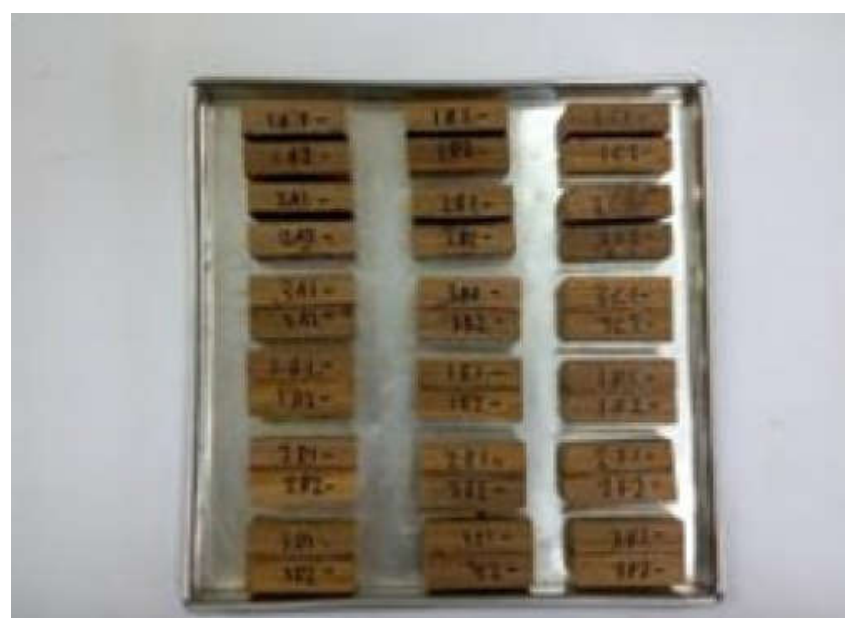

Gambar 5. Kondisi sampel kayu yang direkat pada pengujian daya tahan setelah 10 siklus

Pengujian daya tahan perekat menunjukkan bahwa sampel kayu yang direkatkan menggunakan tanin dengan pelarut etanol dan aceton terlepas pada siklus pertama. Perekat terlepas ketika diberikan perlakuan dengan ditempatkan pada kelembaban 95\% dalam inkubator. Hal ini menunjukkan bahwa perekat dari tanin dengan pelarut etanol dan aceton tidak mampu bertahan pada kelembaban yang tinggi. Kondisi yang lain pada siklus pertama, sampel kayu yang direkatkan dengan perekat yang lain masih dalam kondisi baik.

Sampai dengan siklus ke-10, 4 (empat) sampel kayu yang direkat masih dalam kondisi baik. Tidak ada sampel kayu yang terlepas pada setiap jenis perlakuan. 
Hal ini menunjukkan bahwa perekat tanin dengan pelarut formaldebyde dan perekat gondorukem dengan pelarut tiner, minyak cat dan toluol dapat bertahan pada fluktuasi suhu dan kelembaban udara yang tinggi.

\subsection{Pengujian Kekuatan Perekat}

1. Pengujian kualitatif kekuatan rekat dengan beban statis

Pengujian dilakukan untuk mengetahui kekuatan perekat ketika diberikan beban dengan berat tertentu. Selain itu, perekat juga dilakukan pengujian kuat geser dengan alat universal testing machine. Mula-mula sampel kayu yang direkatkan dipasang pengait pada sisi atas dan bawah. Pengait di bagian atas dipakai untuk menggantung sampel yang direkat pada pada papan, sedangkan pengait di bagian bawah dipakai untuk menggantung pemberat pada sampel yang direkat.

Pada Gambar 6 terlihat sampel kayu yang direkatkan digantung pada papan tanpa diberikan tambahan pemberat. Pengujian ini dilakukan
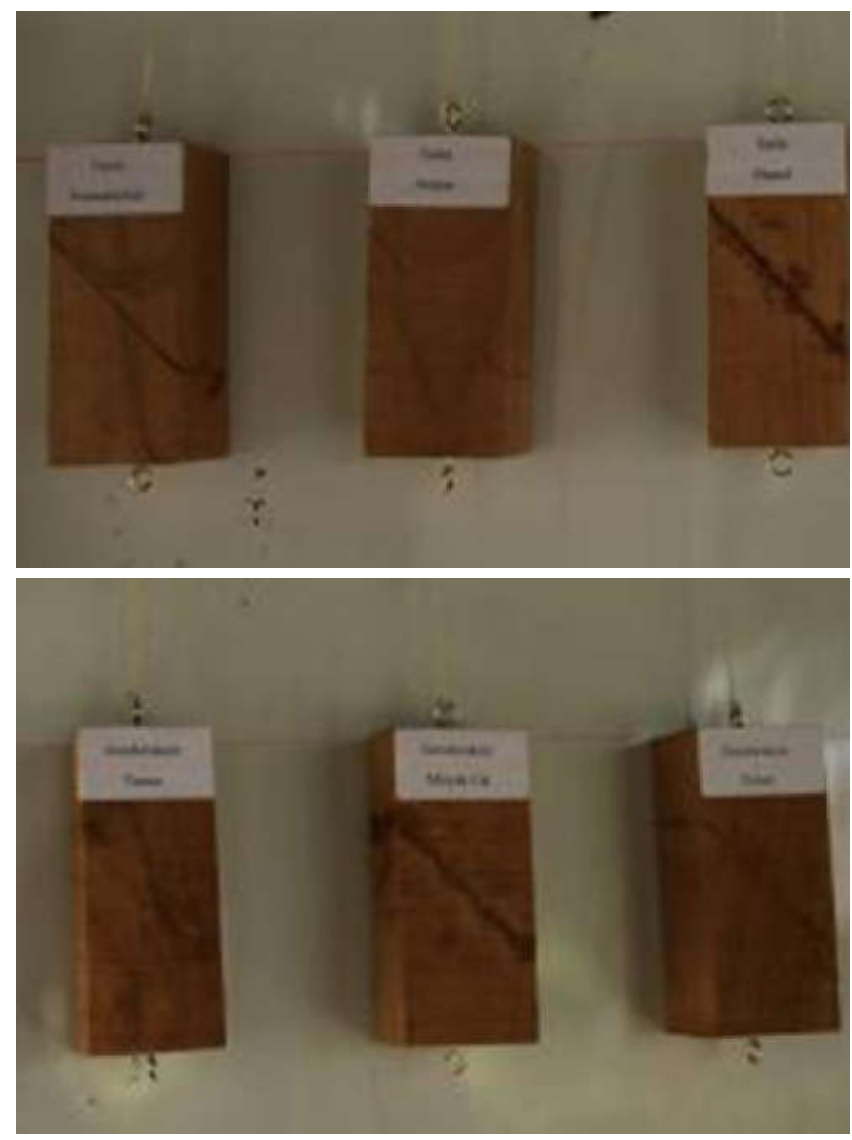

Gambar 5. Sampel kayu yang direkat dipasang pengait di bagian atas dan bawah

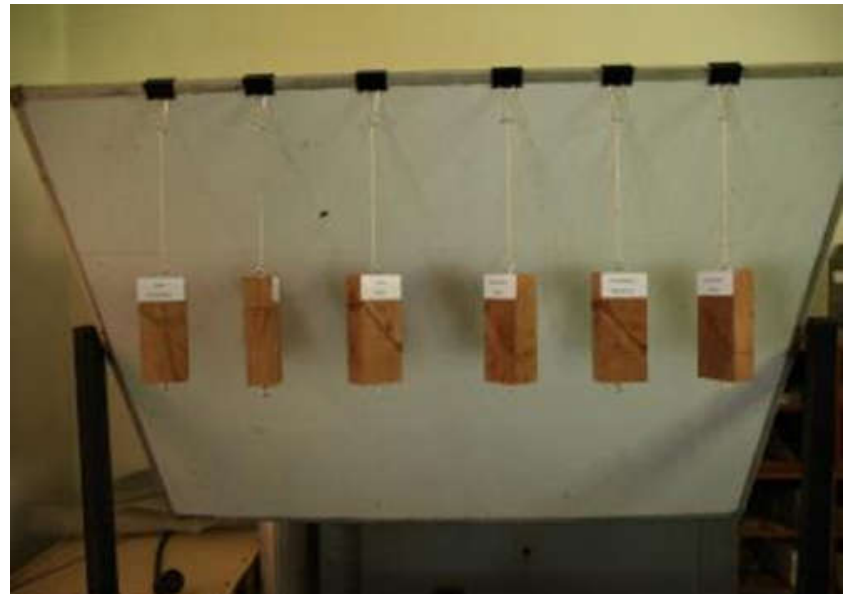

Gambar 6. Sampel kayu yang direkat digantung pada papan, berturut-turut dari kiri ke kanan: tannin-formaldehyde, tanninaceton, tannin-etanol, gondorukem-tiner, gondorukem-minyak cat, gondorukem-toluol

selama 7 hari untuk mengetahui kekuatanperekat terhadap beban kayu itu sendiri. Pada pengujian ini sampel kayu yang direkatkan dengan tanin dan pelarut etanol lepas pada hari ke-7, sedangkan 5 (lima) sampel yang lain masih bertahan dan dilanjutkan dengan pengujian selanjutnya.

Pengujian selanjutnya terhadap 5 (lima) sampel kayu yang masih bertahan diberikan tambahan pemberat. Pemberat yang dipakai adalah batu andesit dengan berat 0,5 kg; $1 \mathrm{~kg} ; 1,5 \mathrm{~kg}$ dan $2 \mathrm{~kg}$. Pengujian untuk pemberat 0,5 kg; $1 \mathrm{~kg}$ dan 1,5 $\mathrm{kg}$ dilakukan selama 2 hari (48 jam), sedangkan untuk pemberat $2 \mathrm{~kg}$ dilakukan selama 7 hari. Sampel kayu yang lolos pengujian dengan pemberat 0,5 kg akan berlanjut untuk pengujian dengan pemberat $1 \mathrm{~kg}$, dan seterusnya sampai

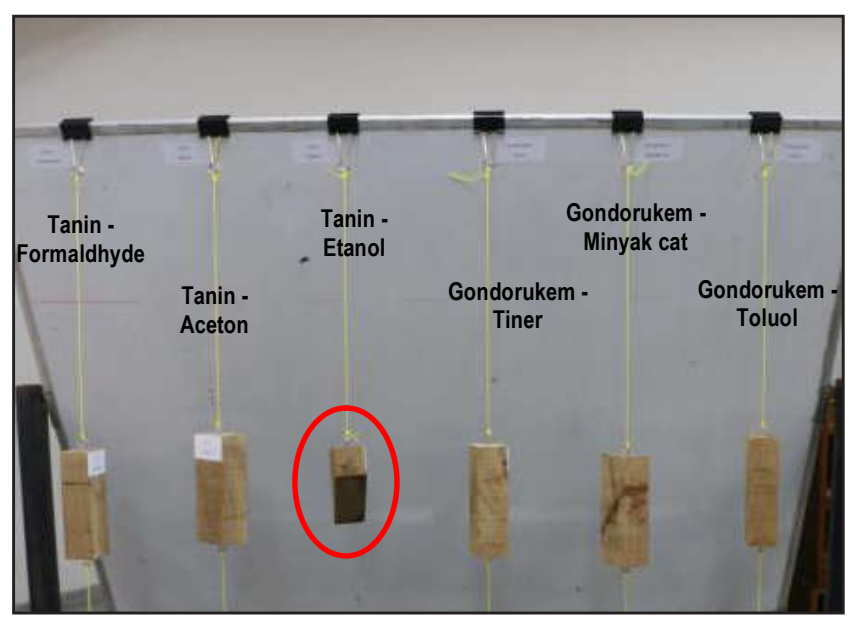

Gambar 7. Sampelkayu yang direkat dengan tanin+etanol lepas sebelum diberi tambahan pemberat pada hari ke-7 
dengan pemberat $2 \mathrm{~kg}$.

Hasil pengujian dengan pemberat $0,5 \mathrm{~kg}$ selama 2 hari, 5 (lima) sampel kayu yang direkat masih bertahan. Tidak ada sampel yang lepas selama pengujian ini, dan pengujian dilanjutkan dengan pemberat $1 \mathrm{~kg}$.

Hasil pengujian dengan pemberat $1 \mathrm{~kg}$ selama 2 hari, pada hari ke-1, 5 (lima) sampel kayu yang direkatkan masih bertahan. Pada hari ke-2 sampel kayu yang direkat dengan tanin dan aceton terlepas, sedangkan 4 (empat) sampel yang lain masih bertahan. Selanjutnya 4 (empat) sampel yang masih bertahan dilakukan pengujian dengan pemberat $1,5 \mathrm{~kg}$.

Pada pengujian dengan pemberat 1,5 kg selama 2 hari, 4 (empat) sampel kayu yang direkat masih bertahan. Tidak ada sampel yang terlepas selama pengujian ini, dan selanjutnya pengujian dilakukan dengan pemberat $2 \mathrm{~kg}$.

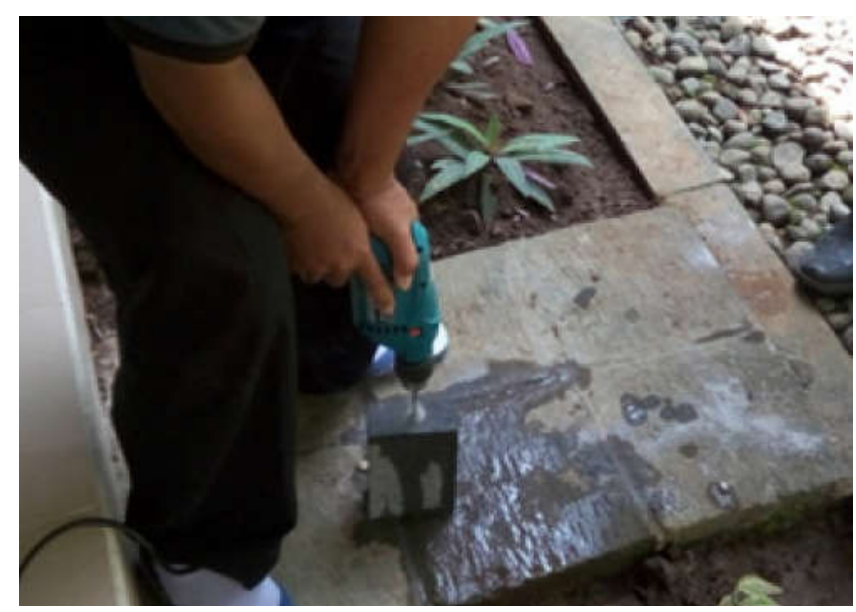

Gambar 8. Pembuatan pemberat dari andesit

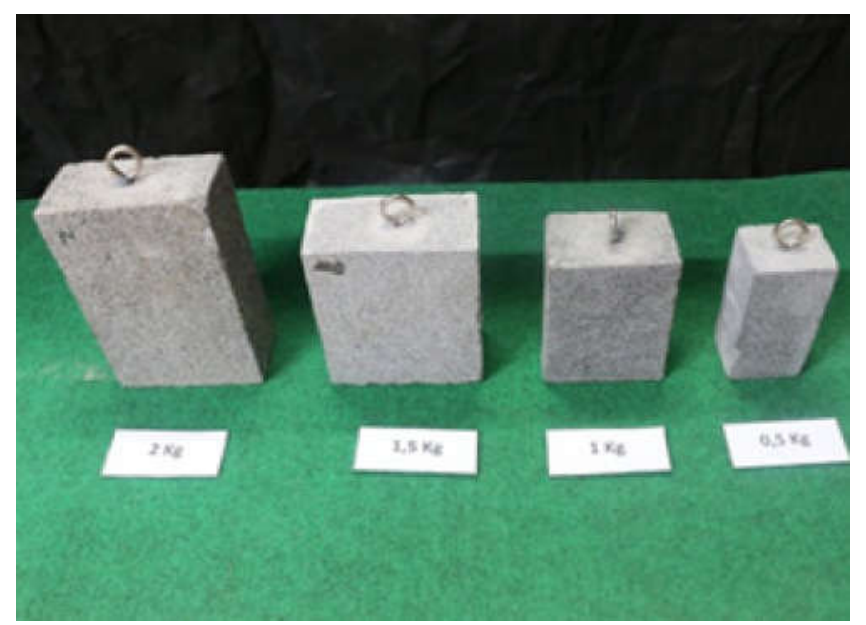

Gambar 9. Pemberat dari andesit dengan berat $2 \mathrm{~kg} ; 1,5 \mathrm{~kg} ; 1 \mathrm{~kg}$; $0,5 \mathrm{~kg}$

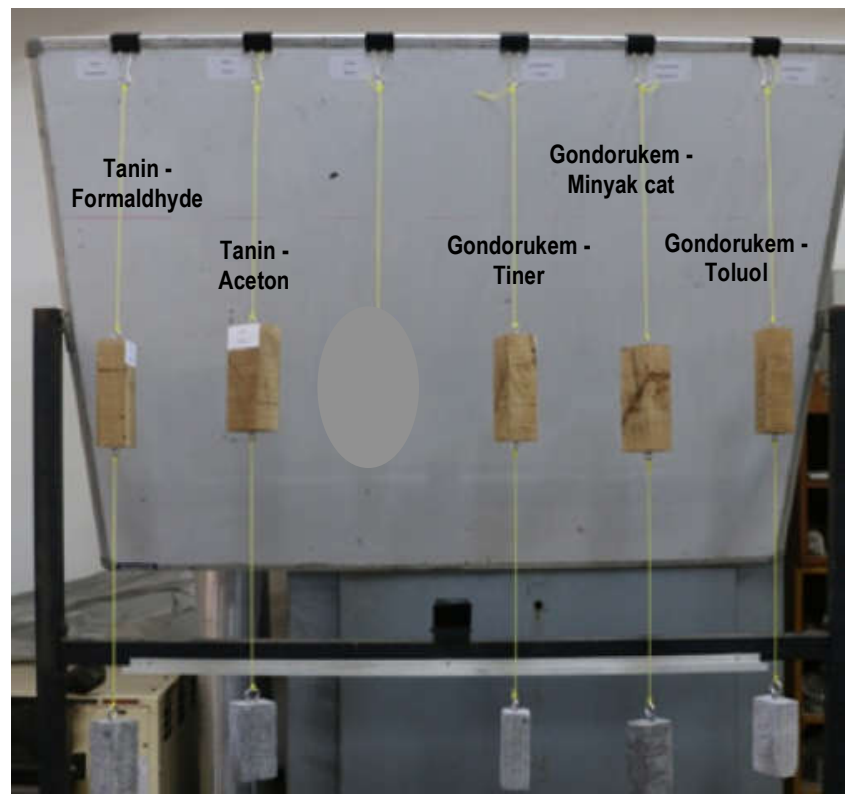

Gambar 10. Pengujian kekuatan perekat dengan pemberat $0,5 \mathrm{~kg}$, tidakada sampel yang lepas (lima sampel bertahan)

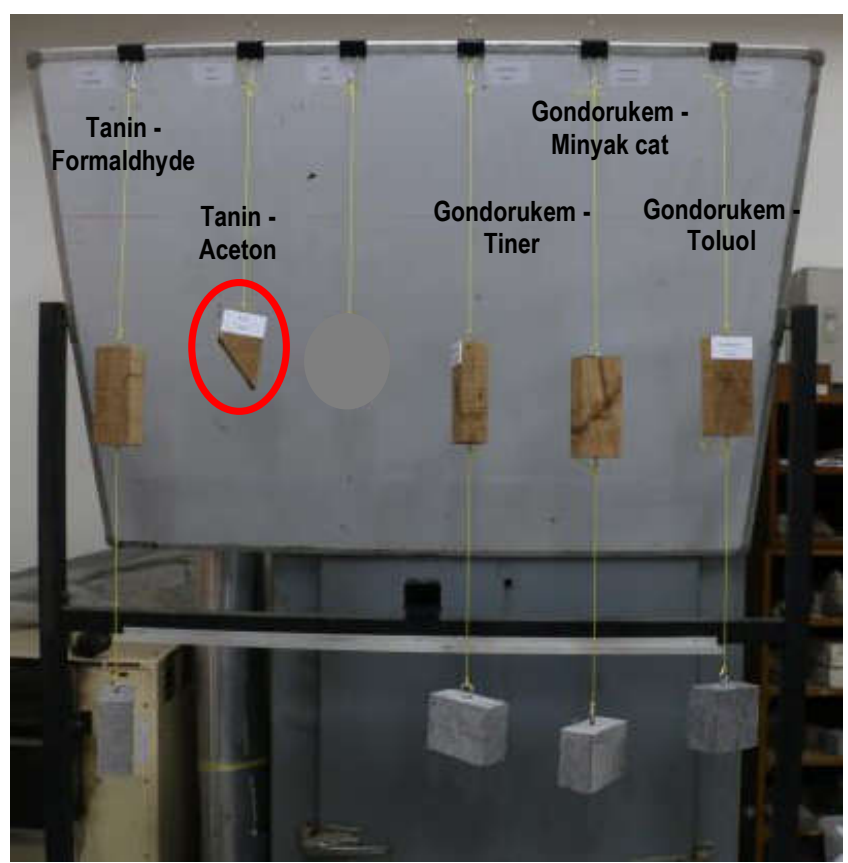

Gambar 11. Pengujian kekuatan perekat dengan pemberat $1 \mathrm{~kg}$, sampel kayu yang direkat dengan tannin dan acetonlepas.

Pada pengujian dengan pemberat $2 \mathrm{~kg}$ selama 7 hari, 4 (empat) sampel kayu yang direkatkan masih bertahan. Selanjutnya perekat yang masih bertahan dilakukan pengujian kuat geser.

2. Pengujian kuat geser

Pengujian kuat geser perekat dilakukan dengan 2 cara, yaitu perekat diposisikan pada kemiringan $90^{\circ}$ dan $45^{\circ}$. Pengujian kuat geser dengan kemiringan sambungan $90^{\circ}$, sampel 


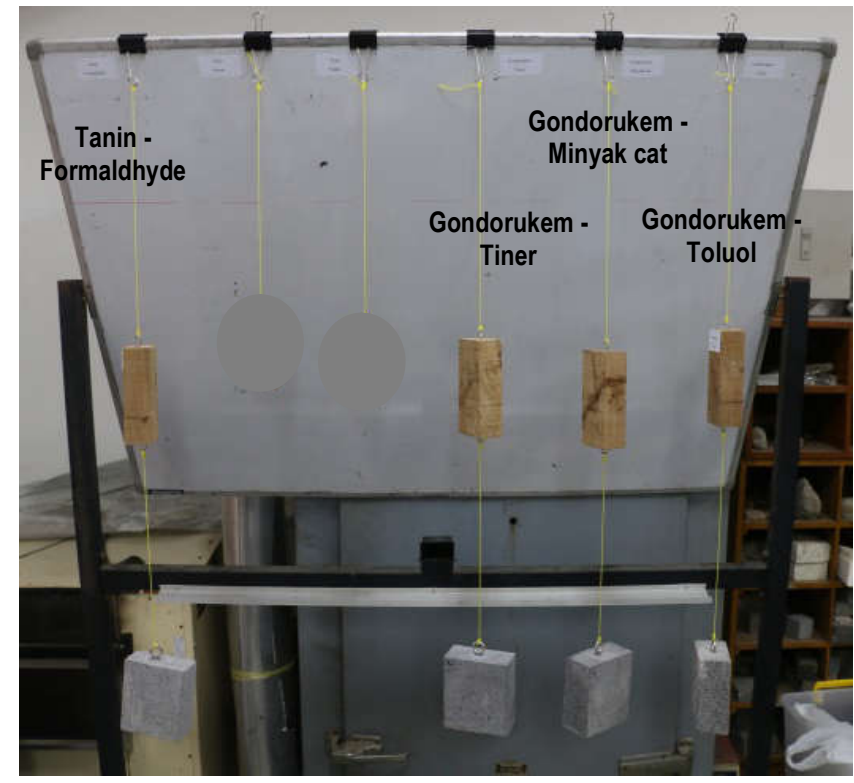

Gambar 12. Pengujian kekuatan perekat dengan pemberat $1,5 \mathrm{~kg}$, tidak ada sampel yang lepas (empat sampel bertahan)

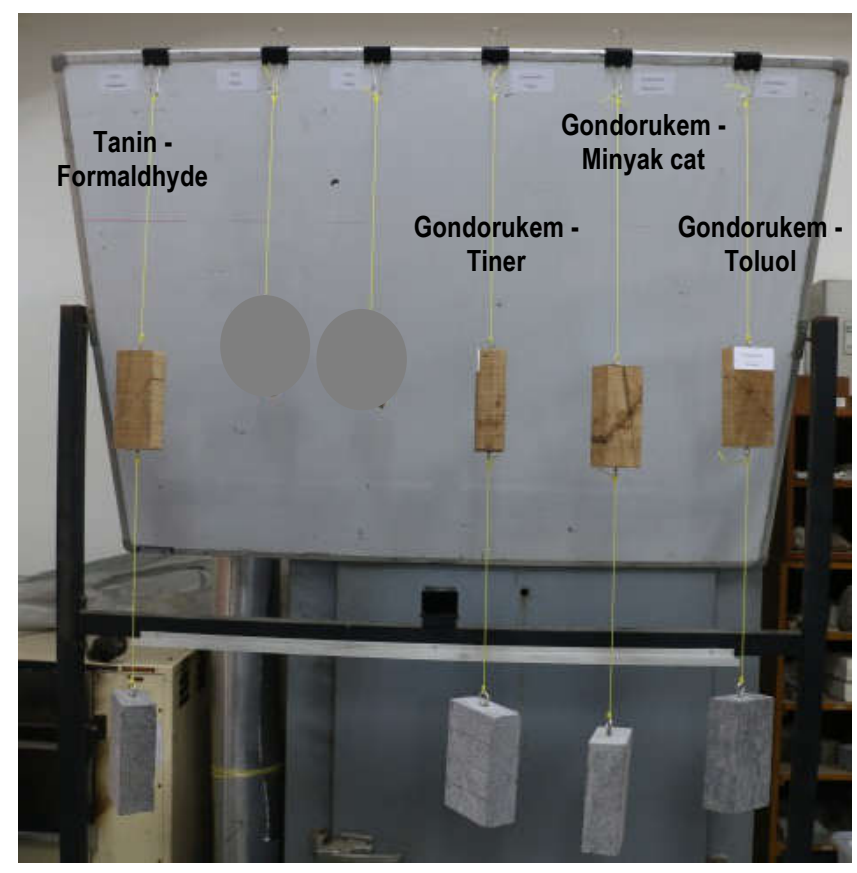

Gambar 13. Pengujian kekuatan perekat dengan pemberat $2 \mathrm{~kg}$ selama 7 hari, tidak ada sampel yang lepas (empat sampel bertahan)

yang digunakanberukuran $5,5 \mathrm{~cm} \times 1,5 \mathrm{~cm} \times$ $1,5 \mathrm{~cm}$ yang direkatkan dengan sampel yang berukuran sama pada posisi memanjang, sehingga sampel ukuran sampel menjadi $5,5 \mathrm{~cm}$ x $3 \mathrm{~cm} \times 1,5 \mathrm{~cm}$. Sedangkan untuk pengujian kuat geser dengan kemiringan sambungan $45^{\circ}$, sampel yang digunakanberukuran $15 \mathrm{~cm} \times 7 \mathrm{~cm}$ $\mathrm{x} 4 \mathrm{~cm}$ yang dipotong menjadi 2 bagian pada arah memanjang dengan kemiringan $45^{\circ}$ untuk kemudian direkatkan.

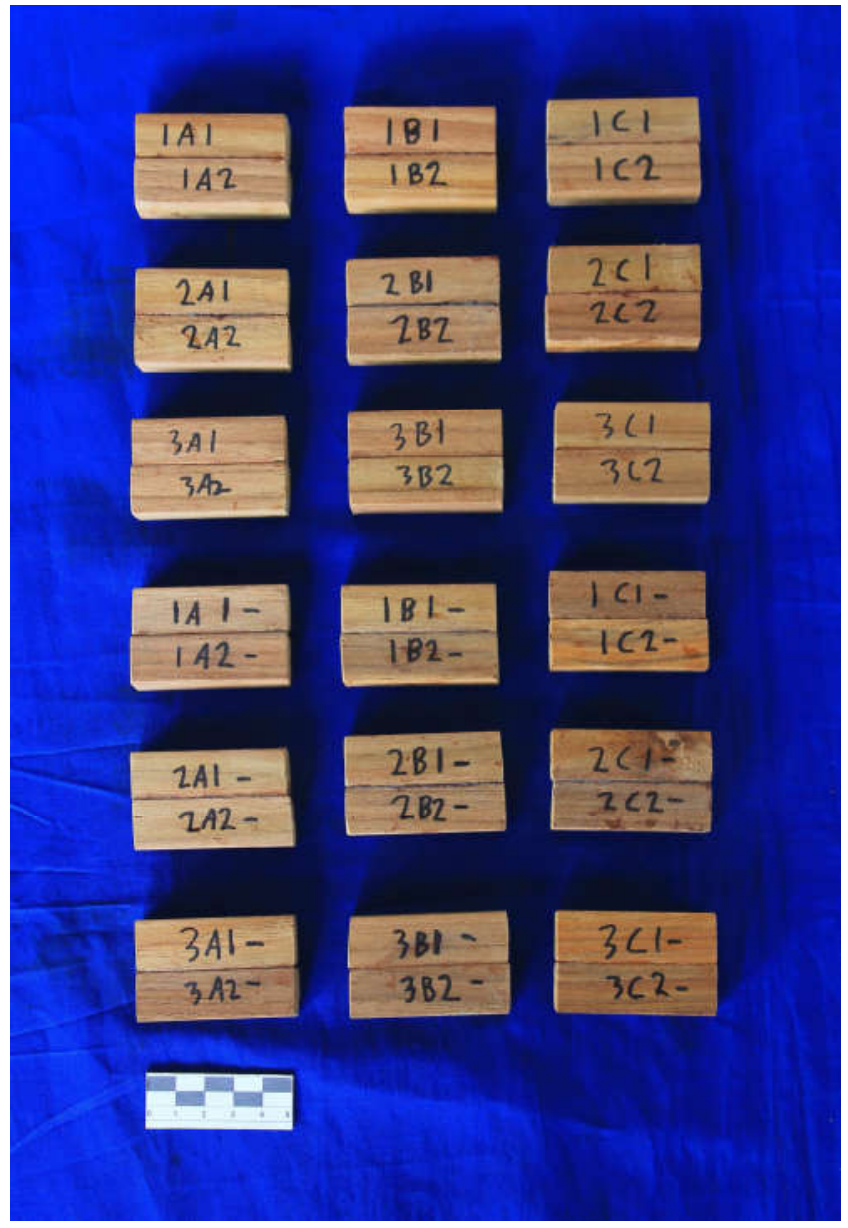

Gambar 14. Sampel untuk pengujian kuat geser dengan kemiringan $90^{\circ}$

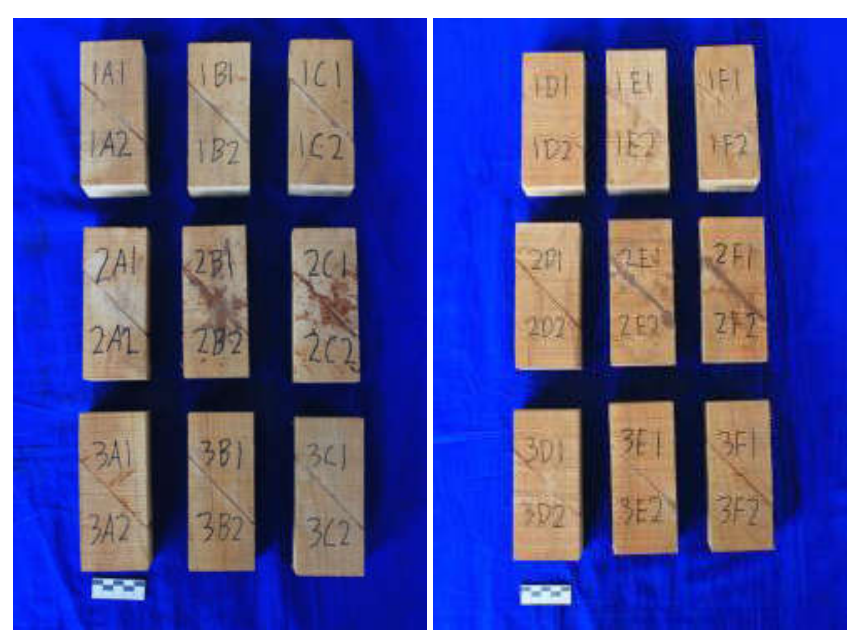

Gambar 15. Sampel untuk pengujian kuat geser dengan kemiringan $45^{\circ}$

Pengujian sampel dengan kemiringan sambungan $90^{\circ}$ menggunakan pasangan alat yang dipakai untuk pengujian perekat yang dihubungkan dengan UTM (Universal Testing Machine). Prinsip kerja dari pengujian ini adalah salah satu sisi kayu yang direkatkan ditahan dengan penjepit, sementara sisi lainnya dalam kondisi bebas. Sisi 
yang bebas kemudian ditekan dengan balok besi yang telah dihubungkan dengan UTM sampai terlepas. Nilai kuat geser dihitung dari beban yang diterima ketika sambungan kayu terlepas (kg) dibagi dengan luas penampang yang direkat $\left(\mathrm{cm}^{3}\right)$. Perhitungannya adalah sebagai berikut :

\section{$\mathbf{C}=\mathbf{P}$ \\ A}

keterangan :

$\mathrm{C}=$ kuat geser perekat $\left(\mathrm{kg} / \mathrm{cm}^{2}\right)$

$\mathrm{P}=$ beban yang diterima $(\mathrm{kg})$

$\mathrm{A}=$ luas permukaan bidang yang direkat $\left(\mathrm{cm}^{2}\right)$

Pengujian sampel dengan kemiringan sambungan $45^{\circ}$ menggunakan alatUTM dengan prinsip kerja seperti pada pengujian kuat tekan. Dua fragmen kayu yang telah direkatkan secara diagonal dengan sudut $45^{\circ}$, ditekan dengan alat UTM hingga sambungan terlepas. Nilai kuat geser dihitung dari beban yang diterima ketika sambungan kayu terlepas (kg) dibagi dengan luas penampang yang direkat $\left(\mathrm{cm}^{3}\right)$ kemudian dikalikan dengan $\cos 45^{\circ}$. Perhitungannya adalah sebagai berikut :

\section{$C=P \times \cos 45^{\circ}$}

A

keterangan :

$\mathrm{C}=$ kuat geser perekat $\left(\mathrm{kg} / \mathrm{cm}^{2}\right)$

$\mathrm{P}=$ beban yang diterima $(\mathrm{kg})$

$\mathrm{A}=$ luas permukaan bidang yang direkat $\left(\mathrm{cm}^{2}\right)$

Hasil pengujian kuat geser terhadap seluruh sampel perekat dengan kemiringan $90^{\circ}$ tidak dapat dibaca oleh alat UTM. Hal tersebut dapat disebabkan karena skala kekuatan UTM yang digunakan terlalu

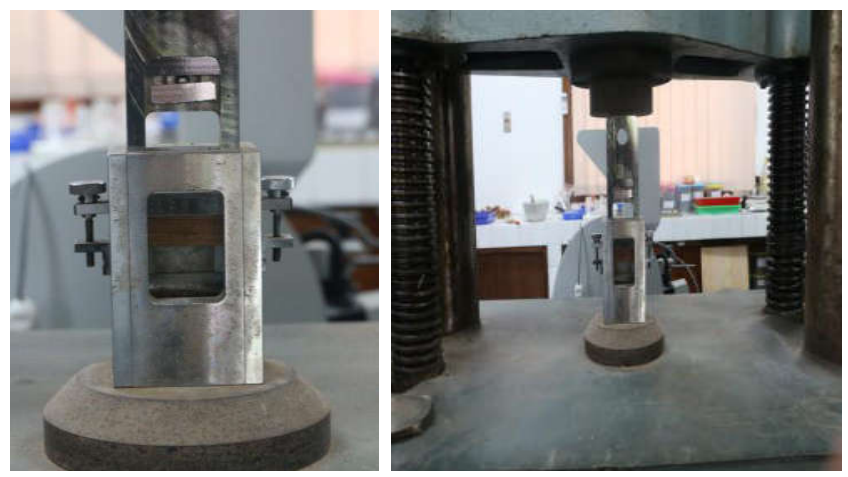

Gambar 16. Pengujian kuat geser perekat dengan kemiringan $90^{\circ}$

besar. Begitu pula untuk sampel pembanding yang diuji menggunakan perekat pabrikan juga tidak terbaca. Sedangkan untuk pengujian kuat geser perekat dengan kemiringan $45^{\circ}$ didapatkan hasil seperti pada Tabel 3.

Berdasarkan pada percobaan yang telah dilakukan, pengujian kekuatan perekat masih perlu dilakukan pengujian kuat geser pada kemiringan $90^{\circ}$ dengan alat yang memiliki skala kekuatan yang rendah. Selain itu, diperlukan juga pengujian kuat tarik perekat.

\section{Penutup}

\subsection{Kesimpulan}

1. Dari pengujian daya tahan, perekat tanin dengan pelarut formaldehyde dan perekat gondorukem dengan pelarut tiner, minyak cat dan toluol mampu bertahan pada fluktuasi suhu dan kelembaban udara yang tinggi. Sedangkan perekat tanin dengan pelarut etanol dan aceton akan terlepas pada kondisi kelembaban udara yang tinggi.

2. Dari hasil pengujian kualitatif kekuatan rekat dengan beban statis, perekat dari tanin dengan

Tabel 3. Kuat geser perekat pada kemiringan $45^{\circ}$

\begin{tabular}{|c|c|c|c|c|}
\hline No & Bahan & Pelarut & $\begin{array}{l}\text { Kuat geser } \\
(\mathrm{kg} / \mathrm{cm} 2)\end{array}$ & Keterangan \\
\hline 1 & Tanin & Etanol & - & \multirow{3}{*}{$\begin{array}{l}\text { Tidak dilakukan pengukuran karena tidak lolos pengujian beban } \\
\text { statis }\end{array}$} \\
\hline 2 & Tanin & Aceton & - & \\
\hline 3 & Tanin & Formaldehyde & 9,95 & \\
\hline 4 & Gondorukem & Tiner & 9,52 & \\
\hline 5 & Gondorukem & Minyak cat & 4,81 & \\
\hline 6 & Gondorukem & Toluol & 14,83 & \\
\hline
\end{tabular}


pelarut etanol dan aceton tidak direkomendasikan karena kekuatannya sangat rendah.

3. Hasil pengujian kuat geser perekat dengan kemiringan $90^{\circ}$, semua sampel yang diuji tidak terbaca oleh alat. Hal ini mungkin disebabkan karena skala kekuatan UTM yang dipakai terlalu besar untuk sampel yang diuji.

4. Hasil pengujian kuat geserperekat pada kemiringan $45^{\circ}$, perekat gondorukem dengan pelarut toluol memiliki kekuatan yang paling

\section{DAFTAR PUSTAKA}

Hartomo, A.J., Rusdiharsono, A., Hardjanto, D., 1992, Memahami Polimer dan Perekat, Yogyakarta.

Ningsih, Elya, 2015, Pengaruh Subu Kempa dan Komposisi Perekat Asam Sitrat- Pati Terhadap Sifat Fisikea Mekanika Papan Partikel Bambu Petung. Skripsi. Fakultas Kehutanan UGM (http://etd.repository. ugm.ac.id/index.php? mod=review \&sub= review \&a ct $=$ view $\&$ t y p $=$ html $\&$ buku_ $\mathrm{id}=78976 \&$ obyek_id=4\&unitid=1\&jenis_id=)

Nugraha, Adi. \& Nirma Noermala, 2013, Pemanfaatan Lignin Hasil Proses Delignifikasi Pulp dari Kulit Buah Kakao sebagai Perekat. Penelitian. UPN Veteran, Jawa Timur. tinggi $(14,83 \mathrm{~kg} / \mathrm{cm} 2)$. Berturut-turut dibawahnya adalah perekat tanin dengan pelarut formaldehyde $(9,95 \mathrm{~kg} / \mathrm{cm} 2)$, gondorukem dengan pelarut tiner $(9,52 \mathrm{~kg} / \mathrm{cm} 2)$ dan gondorukem dengan pelarut minyak cat $(4,81$ $\mathrm{kg} / \mathrm{cm} 2)$.

5. Perlu dilakukan pengujian kuat geser perekatpada kemiringan $90^{\circ}$ dengan alat yang memiliki skala kekuatan yang rendah dan juga masih perlu dilakukan pengujian kuat tarik perekat.

Santoso, A, 2003, Pemanfaatan Lignin dan Tanin sebagai Alternatif Substitusi Bahan Perekat Kayu Komposit. Prosiding Simposium Nasional Polimer V. Pusat Pengembangan dan Penelitian Hasil Hutan, Bogor. (http://digilib.batan.go.id/e-prosiding/ File\%20Prosiding/Kimia/Polimer-V2005/Adisantoso155.pdf)

Suryana, D., 2013, Cara Membuat Lem, Dayat Suryana, Bandung.

Umemura, K. 2006. Wood-based materials and wood adhesives: Recent trend in Japan : Makalah Wood Science School di UPT Biomaterial LIPI, Cibonong. 